\title{
EFEKTIVITAS KEBIJAKAN PENATAUSAHAAN PADA PENGELOLAAN BARANG MILIK NEGARA DI BALAI PENDIDIKAN DAN PELATIHAN KEAGAMAAN MEDAN
}

\author{
Rizkia Daulay ${ }^{1}$, Anthony Hardinal Sijabat ${ }^{2}$
}

Balai Diklat Keagamaan Medan Jl. TB. Simatupang No. 122 Medan Telp. (061)8456256

E-mail: rezky.dly@gmail.com anthonysijabat1@gmail.com Naskah diterima: 18 Mei 2021 Naskah Direvisi: 12-20 Oktober 2021 Naskah disetujui: 3 Desember 2021

\begin{abstract}
ABSTRAK
Penelitian ini bertujuan untuk melihat Efektivitas Kebijakan Penatausahaan Barang Milik Negara di Balai Diklat Keagamaan Medan. Lokasi penelitian dilakukan di Balai Diklat Keagamaan Medan yang beralamat di Jalan TB. Simatupang No. 122 Medan. Permasalahan yang diangkat dalam penelitian ini adalah aset yang berpindah-pindah ruangan tanpa sepengetahuan pengelola Barang Milik Negara sehingga tidak diketahui keberadaannnya yang berdampak pada catatan pengelolaan aset yang tidak menujukan data rill di lapangan dan pengelola Barang Milik Negara yang masih sangat minim sumber daya manusianya serta kurangnya kesadaran para pengguna barang terkait penatausahaan Barang Milik Negara. Penelitian ini menggunakan metode penelitian kualitatif, digunakan dalam suatu penelitian untuk memperoleh gambaran secara kualitatif dan akan banyak didominasi oleh kata-kata, kalimat maupun uraian serta jarang menggunakan data-data angka. Dalam membahas permasalahan yang ada penulis menggunakan teori efektivitas Campbell dan Duncan. Hasil penelitian menunjukan adanya permasalahan yang menjadikan kurang efektifnya kebijakan penatausahaan Barang Milik Negara yang disebabkan kurangnya pelaksanaan inventarisasi dan faktor kurangnya sumber daya pengelola barang milik negara, maka dengan lebih memahami kebijakan penatausahaan barang milik negara akan memberikan dampak yang signifikan terhadap perbaikan penatausahaan barang milik negara sehingga menghasilkan penatausahaan barang milik negara yang lebih efektif.
\end{abstract}

Kata Kunci: Efektivitas, Kebijakan, Barang Milik Negara, Pembukuan, Inventarisasi, Pelaporan

\footnotetext{
ABSTRACT

The research aims to describe the effectiveness policy at Balai Diklat Keagamaan Medan. The location of the research was conducted at Balai DIklat Keagamaan Medan, which is located at Jalan TB Simatupang No. 122 Medan. The problem raised in this research such as assets that move around the room without the knowledge of the manager of state property so that their whereabouts are not known which has an impact on assets management records that do not address real data in the field and state property managers who still have very minimal human resources and lack of human resources as users related to the administration of state property. This research uses qualitative research methods. It is used in a study to obtain a qualitative description and will be dominated by words, sentences, and descriptions and rarely uses numerical data. In discussing the existing problems, the writers use Campbell and Duncan's theory of effectiveness.
} 
The result of the study shows that there are problems that make the policy of administering state property ineffective due to the lack of inventory implementation and the lack of resources for managing state-owned goods so that a better understanding of the policy of administering state-owned goods will have a significant impact on improving the administration of state-owned goods so that resulting in a more effective administration of state-owned goods.

Keywords: Effectiveness, Policy, State Property, Bookkeeping, Inventory, Reporting

\section{PENDAHULUAN}

Dalam rangka mewujudkan good governance salah satu kebijakan yang telah dilakukan oleh pemerintah adalah kebijakan dalam Penatausahaan Barang Milik Negara (BMN). Barang Milik Negara merupakan hal yang tak terpisahkan dari penatausahaan dan pertanggungjawaban mengingat Barang Milik Negara menurut Peraturan Menteri Keuangan Republik Indonesia Nomor 181/PMK.06/2016

Tentang Penatausahaan Barang Milik Negara ialah semua barang yang dibeli atau diperoleh atas beban Anggaran Pendapatan dan Belanja Negara atau berasal dari perolehan lainnya yang sah.

Barang Milik Negara yang selanjutnya disingkat BMN memiliki peran yang sangat penting dalam mendukung pelaksanaan kegiatan pemerintahan menurut Peraturan Presiden Nomor 54 tahun 2010 Pengertian Barang adalah setiap benda baik berwujud maupun tidak berwujud, bergerak maupun tidak bergerak, yang dapat diperdagangkan, dipakai, dipergunakan atau dimanfaatkan oleh Pengguna Barang. Pelaksana Penatausahaan adalah unit yang melakukan Penatausahaan BMN pada Kuasa Pengguna Barang, Pengguna Barang, dan Pengelola Barang. Didalam Peraturan Menteri Keuangan Republik
Indonesia Nomor 181/PMK.06/2016 Tentang Penatausahaan Barang Milik Negara menyebutkan bahwa Barang milik negara pada lembaga pemerintahan perlu ditetapkan penatausahaan yang baik mengingat pelaksanaan Penatausahaan BMN wajib melakukan Pembukuan, Inventarisasi dan Pelaporan BMN sesuai dengan peraturan perundang-undangan.

Objek Barang Milik Negara yang akan diteliti sesuai dengan peraturan kemenkeu mengenai penatausahaan adalah tanah, peralatan mesin, gedung dan bangunan.

Pengelolaan Barang Milik Negara di lingkungan Balai Pendidikan dan Pelatihan Keagamaan Medan masih belum berjalan dengan sempurna, hal ini terlihat dalam penerapan pengelolaannya masih ditemukan kekurangan pada pelaksanaan kebijakan penatausahaan Barang Milik Negara pada Balai Pendidikan dan Pelatihan Keagamaan Medan seperti permasalahan aset yang berpindahpindah ruangan tanpa sepengetahuan pengelola Barang milik negara sehingga tidak diketahui keberadaannnya yang tentunya berdampak pada catatan pengelolaan aset yang tidak menujukan data rill di lapangan dan didukung kurangnya kesadaran para pengguna barang dalam hal pengamanan barang milik negara sehingga barang dengan 
mudahnya dapat berpindah-pindah serta belum adanya pemberiaan Label pada Aset sedangkan pemberian label pada aset harus dilakukan untuk mengetahui berapa jumlah aset tersebut dan tahun berapa perolehan asetnya sehingga hal ini membantu dalam penginventarisasian BMN yang dilakukan setiap tahunnya.

Penatausahaan Barang Milik Negara ini sangat penting untuk penataan aset negara tidak hanya dari segi rekonsiliasi laporan namun juga implementasi di lapangan dalam pengelolaan Barang Milik Negara. Penelitian yang dilakukan sebelumnya oleh Nurwahid (2013) dengan Judul Implementasi Penatausahaan Barang Milik Negara di KPPN Palembang menunjukan bahwa penatausahaan Barang Milik Negara sangat di Pengaruhi oleh Pembukuaan, Inventarisasi dan Pelaporan yang merupakan bagian dari kebijakan penatausahaan BMN dalam peneltian tersebut menyatakan bahwa penatausahaan barang milik negara belum efektif pelaksanaannya dikarenakan faktor sumberdaya manusia pengelolanya yang masih kurang.

\section{METODOLOGI PENELITIAN}

Penelitian

ini

betujuan

mengetahui dan menggambarkan bagaimana Efektivitas Kebijakan Penatausahaan Barang Milik Negara di lingkungan Balai Pendidikan dan Pelatihan Keagamaan Medan.

Penulis tertarik melakukan penelitian mengenai kebijakaan penatausahaan BMN di lingkungan Balai Pendidikan dan Pelatihan Keagamaan Medan dikarenakan sosialisasi pelaksanaan penatausahaan BMN belum berjalan tertata dengan baik.

Dengan demikian penelitian akan mengarah pada penelitian deskriptif kualitatif yang lebih menekankan pada pengungkapan makna dari efektivitas kebijakan penatausahaan barang milik negara serta faktor-faktor kendalanya

Penelitian kualitatif ialah penelitian yang berupaya membangun pandangan orang yang diteliti secara rinci serta dibentuk dengan kata-kata, gambaran holistik (menyeluruh dan mendalam) dan rumit (Tohirin, 2013). Sedangkan menurut Syamsuddin dan Damaianti (2006) Penelitian kualitatif adalah suatu pendekatan yang juga disebut pendekatan investigasi karena biasanya peneliti mengumpulkan data dengan cara bertatap muka langsung dan berinteraksi dengan orang-orang di tempat penelitian.

Dalam penelitian ini peneliti dituntut dapat menggali berdasarkan apa yang diucapkan, dirasakan dan dilakukan oleh partisipan atau sumber data. Peneliti kualitatif harus bersifat "perspektif emic". Pengertian dari perspektif emic yaitu data yang diperoleh harus "sebagaimana seharusnya", sesuai dengan budaya yang ada dalam lingkungan tersebut, bukan berdasarkan apa yang dipikirkan oleh peneliti, tetapi berdasarkan sebagaimana adanya yang terjadi dilapangan, yang dialami, dirasakan, dipikirkan oleh partisipan/sumber data (Sugiyono, 2016). Perspektif ini bertentangan dengan perspektif etik yang lebih mementingkan sudut pandang orang luar sebagai dasar untuk generalisasi fokus penelitian.

Penelitian dilakukan di lingkungan Balai Pendidikan dan Pelatihan 
Keagamaan Medan yang merupakan Unit Pelaksana Teknis Badan Litbang dan Diklat Kementerian Agama yang menangani bidang pendidikan dan pelatihan di lingkungan Kementerian Agama di daerah. Sebagai kepanjangan tangan dari Badan Litbang dan Diklat Kementerian Agama yang terletak di Jalan T.B. Simatupang No. 122 Medan. Balai Pendidikan dan Pelatihan Keagamaan Medan merupakan salah satu lembaga yang berada dibawah naungan Kementerian Agama yang wajib menerapkan kebijakan yang telah dikeluarkan Kementerian Keuangan terkait kebijakan penatausahaan barang milik negara yakni Peraturan Menteri Keuangan Republik Indonesia Nomor 181/PMK.06/2016

Tentang

Penatausahaan Barang Milik Negara. Waktu penelitian dilakukan mulai dari bulan April sampai dengan Mei 2021

Dalam penelitian

ini, dipergunakan dua

sumber

pengumpulan data, yaitu pengumpulan data primer dan pengumpulan data sekunder. Sumber data primer adalah sumber data yang langsung memberikan data kepada pengumpul data (Sugiyono, 2013). Dalam penelitian ini peneliti mencari data untuk membuktikan fakta di lapangan. Data primer yang diperoleh berasal dari informan kunci pada Balai Pendidikan dan Pelatihan Keagamaan Medan tahun 2021. Teknik ini dipakai untuk mendapatkan data primer dengan cara peneliti mewawancarai dengan berbagai pertanyaan secara langsung kepada pejabat terkait dengan begitu data-data via wawancara akan dapat diperoleh. Data sekunder adalah sumber data yang tidak langsung memberikan data kepada pengumpul data, tetapi melihat orang lain atau dengan dokumen (Ibid). Dokumen adalah segala bentuk catatan tentang berbagai macam peristiwa atau keadaan masa lalu yang memiliki nilai atau arti penting dan dapat berfungsi sebagai data penunjang dalam penelitian ini. Pengumpulan data sekunder dalam penelitian ini dilakukan dengan penelitian dan pencatatan dokumen antara lain dengan mengumpulkan data dari kantor Balai Pendidikan dan Pelatihan Keagamaan Medan serta kondisi aktual lokasi penelitian.

Analisis data merupakan suatu proses dimana data itu disederhanakan kedalam bentuk yang lebih mudah dibaca dan diiterprestasikan. Materi hasil percakapan dengan para informan disimak kembali dan dipilih secara selektif informasi penting sesuai arah pembahasan, kemudian disesuaikan dengan catatan lapangan/tempat penelitian. Data sekunder yang diperoleh, diteliti dan dicocokkan dengan data yang sama dari narasumber yang berbeda serta pada saat melakukan wawancara peneliti dan pada saat pelaksanaan wawancara peneliti langsung meminta bukti yang terkait dengan data penatausahaan barang milik negara.

Peneliti memilih informan yang dianggap mengetahui dan memiliki informasi tentang pelaksanaan bahkan terlibat langsung dalam penatausahaan barang milik negara di Balai Pendidikan dan Pelatihan Keagamaan Medan, pada penelitian ini informan sebanyak 5 orang yang antara lain (1) Kepala Balai sebagai pejabat struktural tertinggi di Balai Diklat Keagamaan Medan. (2) Kasubag Tata Usaha. (3) Kustodian Barang Milik Negara yang menangani langsung pengelolaan barang milik negara. (4) 
Pengelola Sistem Akutansi Instansi dan (5) Informan tambahan Pengguna Barang Milik Negara.

Mengolah data dan informasi dari informan baik kata-kata atau kalimat untuk diambil intisarinya, sehingga diperoleh konsep-konsep yang mampu menjawab pertanyaan penelitian sehingga tercapai tujuan penelitian yang telah ditetapkan. Hasil dari wawancara yang dilakukan terhadap informan akan dijabarkan pada hasil penelitian, untuk melihat kenyataan penatausahaan barang milik negara berdasarkan pedoman kebijakan penatausahan barang milik negara isi dari wawancara dirangkum dan dikaitkan dengan teori Campbell untuk membahas efektivitas penatausahan barang milik negara.

Setelah memperoleh beberapa konsep yang disimpulkan dan selanjutnya dikembangkan menjadi bahan pembahasan dan penyelesaian permasalahan dalam penelitian. Isi dari wawancara informan kemudian disimpulkan pada pembahasan untuk mengetahui apakah sudah efektif atau belum pelaksanaan penatausahaan barang milik negara di Balai Pendidikan dan Pelatihan Keagamaan Medan dan apakah sudah berpedoman pada Peraturan Menteri Keuangan Republik Indonesia Nomor 181/PMK.06/2016 Tentang Penatausahaan Barang Milik Negara yang mencakup pelaksanaan pembukuan, inventarisasi dan pelaporan.

Dengan teknik analisa data maka akan diperoleh informasi yang luas serta konkrit, terperinci dan lebih mendalam dari beberapa interaksi dan fenonema sosial yang diamati selama proses penelitian
Teknik pengumpulan data merupakan cara untuk mengumpulkan data yang dibutuhkan untuk menjawab rumusan masalah penelitian (Noor, 2012).

Adapun cara untuk mengumpulkan data yang dipergunakan untuk memperoleh informasi dalam penelitian ini yaitu: wawancara, observasi dan dokumentasi.

Wawancara adalah proses tanya jawab dalam penelitian yang berlangsung secara lisan dimana dua orang atau lebih bertatap muka mendengarkan secara langsung informasi /keterangan-keterangan (Cholid, 2008).

Wawancara dilakukan dengan menggunakan pedoman wawancara (interview guide). Percakapan bertujuan menggali informasi oleh peneliti sebagai pewawancara dengan informan sebagai orang yang memberikan jawaban/informasi. Jawaban yang diperoleh dari hasil wawancara akan digunakan untuk memperoleh data yang membutuhkan pendeskripsian. Adapun informan kunci dan informan tambahan sebanyak 5 orang yang merupakan narasumber dalam sebuah penelitian ini antara lain (1) Kepala Balai sebagai pejabat struktural tertinggi di Balai Diklat Keagamaan Medan. (2) Kasubag Tata Usaha. (3) Kustodian Barang Milik Negara yang menangani langsung pengelolaan barang milik negara. (4) Pengelola Sistem Akutansi Instansi dan (5) informan tambahan Pengguna Barang Milik Negara. Teknik pengumpulan data dengan wawancara peneliti langsung mewawancarai informan di lokasi Balai Pendidikan dan Pelatihan Keagamaan kota Medan dengan menggunakan pedoman 
pertanyaan yaitu berdasarkan pengukuran dari keberhasilan efektivitas.

Teknik ini menutut adanya pengamatan dari peneliti baik secara langsung maupun tidak langsung terhadap objek penelitian (Noor, 2012). Dengan adanya observasi langsung, penulis berharap dapat melengkapi teknik wawancara. Beberapa informasi yang diperoleh dari hasil observasi diantaranya: tempat, pelaku, kegiatan, objek, perbuatan, peristiwa dan waktu. Peneliti melihat langsung kelokasi untuk membuktikan kebenaran data yang diminta dengan melihat langsung datadata laporan barang milik negara serta melihat data Kartu Inventaris Barang yang ada disetiap ruangan.

Noor (lbid) menyebutkan bahwa sebagian data yang tersedia yaitu berbentuk surat, data-data, laporan, dan foto. Data sekunder disini penulis peroleh dari inventarisasi pada Balai Pendidikan dan Pelatihan Keagamaan kota Medan yang sudah melaksanakan penatausahaan barang milik negara, peraturan - peraturan tentang penatausahaan barang milik negara dan informasi dari internet terkait kebijakan penatausahaan barang milik negara, serta melihat langsung laporanlaporan yang ada serta data-data kumpulan inventaris baik barang bergerak maupun tidak bergerak.

\section{HASIL DAN PEMBAHASAN}

Efektivitas Kebijakan Penatausahaan Barang Milik Negara di Balai Pendidikan dan Pelatihan Keagamaan Medan dinilai berdasarkan kriteria-kriteria tertentu dalam pencapaian tujuan Penatausahaan Barang Milik Negara (BMN) yang berpedoman berdasarkan Peraturan
Menteri Keuangan Republik Indonesia Nomor 181/PMK.06/2016. adapun indikator sesuatu dapat dikatakan efektif menurut Campbell (dalam Mutiarin, 2014) pengukuran efektivitas secara umum dan yang paling menonjol adalah: (a) Keberhasilan program, Keberhasilan sasaran, c) Kepuasan terhadap program, (d) Kesesuaian input dan output, (e) Pencapaian tujuan menyeluruh.

Campbell (2005) menjelaskan bahwa pengukuran efektivitas suatu kebijakan dapat dilihat dengan antara lain: 1) Keberhasilan program yang merupakan pengukuran efektivitas dalam dalam arti tecapainya tujuan yang telah ditentukan sebelumnya. Efektivitas digunakan sebagai tolok ukur untuk membandingkan antara rencana dan proses yang dilakukan dengan hasil yang dicapai. Sehingga, untuk menentukan efektif atau tidaknya suatu program/kegiatan diperlukan adanya ukuran-ukuran efektivitas.

Keberhasilan sasaran, merupakan pengukuran efektivitas ditinjau dari sudut pencapain tujuan, dimana keberhasilan suatu organisasi harus mempertimbangkan bukan saja sasaran organisasi tetapi juga mekanisme mempertahankan sasaran. Dengan kata lain, peniliain efektivitas harus berkaitan dengan masalah sasaran maupun tujuan.

Pengukuran efektivitas adalah integrasi. Integrasi adalah pengukuran terhadap tingkat suatu organisasi untuk mengadakan sosialisasi. Dimana Integrasi merupakan kemampuan suatu organisasi untuk melakukan sosialisasi pengembangan terhadap organisasi lain dan sosialisasi terhadap organisasi itu sendiri. 
Dimana untuk mencapai agar program yang diinginkan tercapai maka penatausahaan di Balai Diklat Keagamaan Medan sudah mencakup Pembukuan, Inventarisasi serta Pelaporan sesuai dengan Peraturan Menteri Keuangan Nomor 120/PMK06/2007. Berdasarkan hasil wawancara dengan Dr. Salman Al Farisi, S.Ag., M.Pd (Kepala Balai Pendidikan dan Pelatihan Keagamaan Medan) menjelaskan bahwasanya terkait pelaksanaan penatausahaan BMN sudah dilakukan sesuai SOP yang secara garis besar meliputi Pembukuan, Inventarisasi serta pelaporan. (Wawancara tanggal 4 Mei 2021, Pukul 11.00 WIB)

Hasil wawancara dengan Suhesti Wira Dharma., M.A. (Ka. Subbag Tata Usaha): Menyatakan bahwa prosedur penatausahaan BMN sudah dilaksanakan dengan prosedur berdasarkan SOP yang ada (Wawancara tanggal 7 April 2021, pukul 15.30 WIB).

Hasil wawancara dengan Ayulina, S.E (Kustodian Barang Milik Negara) Mengatakan bahwa penatausahaan BMN di Balai Diklat Keagamaan Medan sudah sesuai dengan prosedur yang ditentukan (Wawancara tanggal 28 April 2021, pukul 10.30 Wib)

Hasil wawacara dengan Ichwan Fachriza, S.Pd selaku pengelola sistem akutansi instansi (Wawancara tanggal 28 April 2021, pukul 13.00 Wib) juga menyimpulkan hal yang sama, bahwasanya penataausahaan BMN di Balai Diklat Keagamaan Medan sudah sesuai dengan aturan-aturan yang ditetapkan yang secara garis besar meliputi pembukuan, inventarisasi dan pelaporan.

Drs. Luthfi Maulana Nasution, M.Pd. selaku pengguna barang menyatakan bahwa secara garis besar
Balai Diklat Keagamaan Medan sudah mengikuti aturan yang berlaku terkait Penatausahaan Barang Milik Negara (Wawancara tanggal 4 Mei 2021, Pukul 9.00 WIB).

Berdasarkan hasil wawancara tersebut jika dikaitkan dengan pengukuran efektivitas Campbell J.P maka penatausahaan BMN sudah efektivitas tentunya penatausahaan BMN yang dilaksanakan sudah mengacu pada Permenkeu 120/PMK.06/2007 yang meliputi pelaksanaan pembukuan, inventarisasi dan pelaporan.

Keberhasilan sasaran menurut Campbell J.P adanya suatu mekanisme yang harus dilaksanakan dalam penatausahan barang milik negara agar kebijakan tersebut efektivitas maka harus melakukan inventarisasi. Pelaksanaan inventarisasi merupakan mekanisme untuk mempertahankan kebijakan penatausahaan BMN yang harus dilaksanakan setiap tahunya.

Dalam upaya penatausahaan BMN yang telah ditetapkan sebelumnya adalah perlunya melakukan penginventarisasian BMN agar penatausahaan BMN itu sendiri dapat terus berjalan

Hasil wawancara dengan Dr. Salman Al Farisi, S.Ag., M.Pd (Kepala Balai Pendidikan dan Pelatihan Keagamaan Medan) menjelaskan bahwasanya terkait inventarisasi BMN sudah dilakukan namun belum sempurna dikarenakan ada "pekerjaan rumah" yang harus dilakukan oleh pengelola BMN seperti contohnya DIR atau daftar inventarisasi barang serta harus dilakukan sosialisasi agar pegawai selaku pengguna barang dapat memahami alur serta aturan dalam penggunaan barang milik negara 
(Wawancara tanggal 4 Mei 2021, Pukul 11.00 WIB)

Berdasarkan hasil wawancara dari Suhesti Wira Dharma., M.A. (Ka.Subbag Tata Usaha) yang menjelaskan bahwa penginventarisasian BMN sudah dilakukan tetapi hasilnya belum maksimal (Wawancara Tanggal 7 April Pukul 15.30 Wib) seperti Daftar Inventarisasi Barang yang sudah lama tidak diperbaharui sehingga besar kemungkinan BMN yang ada terkadang sudah tidak riil lagi jumlahnya dengan catatan yang ada dengan fakta barang yang ada dilapangan, dan faktor utama penyebab dari penginventarisasian BMN yaitu SDM yang kurang serta pengguna barang yang kurang memahami bagaimana cara melaksanakan penatausahaan barang milik negara yang sesuai dengan prosedur bahkan timbul rasa kurang perduli terhadap penatausahaan barang milik negara ini terlihat dari yang dilihat langsung oleh peneliti dimana adanya barang yang berpindah dari satu ruangan keruangan lainnya tanpa izin pinjam barang.

Hal ini dikuatkan dengan hasil wawancara dari Ayulina, S.E (Kustodian BMN) yang menyatakan bahwa inventarisasi sudah dilakukan dan terakhir dilakukan di tahun 2019 namun untuk opname barang terakhir dilakukan pada tahun 2015 serta pelabelan kode BMN yang belum ada di beberapa barang serta pengguna BMN yang kurang memahami prosedur penatausahaan BMN seperti tidak pernah ada pelaporan ke pengelola BMN ketika terjadi perpindahan barang milik negara (Wawancara Tanggal 28 April Pukul 10.30 Wib).

Ichwan Fachriza menyatakan bahwa inventarisasi sudah dilakukan namun ada beberapa pekerjaan yang harus dilakukan seperti Daftar Inventarisasi Barang yang sudah lama tidak diperbaharui yang kemungkinan besar data yang tertera berbeda dengan kondisi sebenarnya. Hal ini menurutnya disebabkan oleh kurang nya tenaga SDM yang berhubungan langsung dengan BMN sehingga pelabelan kode BMN sudah lama tidak dilakukan ditambah dengan kurangnya kesadaran pengguna barang milik negara seperti contohnya ketika terjadi perpindahan barang pengguna ruangan tidak melaporkan ke pihak pengelola BMN (Wawancara tanggal 28 April 2021, pukul 13.00 Wib).

Drs. Luthfi Maulana Nasution, M.Pd. selaku pengguna barang juga menyatakan hal yang sama terkait inventarisasi menurutnya ada beberapa hal yang harus segera dilaksanakan seperti contohnya DIR (Daftar Inventarisasi Ruangan) yg sudah lama tidak di perbaharui. (Wawancara tanggal 4 Mei 2021, Pukul 9.00 WIB).

Dari hasil wawancara didapatkan informasi perihal pentausahaan BMN pada pelaksanaan inventaris belum berjalan secara efektif, hal ini dikuatkan dan amati langsung oleh peneliti dapat dilihat pelaksanaan inventarisasi dilakukan pengelola barang milik negara lebih dari 2 tahun ini dibuktikan dengan Kartu Inventaris Barang yang tergantung diruangan sudah 6 tahun belum di perbaharui datanya.

Dan jika mengikuti aturan yang tertera di Permenkeu 120/PMK.06/2007 terlihat jelas bahwa semua instansi pemerintah wajib melaksanakan pelaksanaan inventarisasi dalam setahun sekali.

Inventarisasi merupakan kegiatan yang dilakukan harus dengan teliti mulai 
mengecek barang yang ada disetiap ruangan lalu mencocokan dengan data yang ada di data Sistem Manajemen Akuntansi Barang Milik Negara (SIMAKBMN). Hal ini tentunya membutuhkan tenaga pengelola BMN lebih dari 1 (satu) orang, faktor inilah yang menyebabkan pelaksanaan inventarisasi belum maksimal.

Dari wawancara yang didapatkan dari informan kenyataannya inventarisasi masih jarang dilaksanakan dikarenakan juga faktor Sumber Daya Manusia (SDM) yang masih sangat minim. Dari pengukuran efektivitas Keberhasilan Sasaran menurut Campbell, JP menjelaskan bahwa keberhasilan sasaran merupakan mekanisme mempertahankan dalam hal ini pelaksanaan inventarisasi belum berjalan efektif dan faktor lain kurangnya SDM juga mendukung belum efektifnya keberhasilan sasaran menurut Campbell J.P.

\section{Dalam}

pelaksanaan

penatausahaan BMN para pengelola BMN di Balai Diklat Keagamaan Medan harus berkoordinasi dengan Kantor Pelayanan Kekayaan Negara dan Lelang (KPKNL) dimana KPKNL memiliki peranan dalam hal penatausahaan BMN yaitu dalam hal melaksanakan penetapan status dan penginvetarisasian kembali, serta perlunya melakukan sosialisasi terhadap pegawai dan Widyaiswara Balai Diklat Keagamaan Medan untuk memahami perihal penatausahaan BMN, berdasarkan hal tersebut peneliti membuat wawancara sebagai berikut.

Berdasarkan hasil wawancara dengan Dr. Salman Al Farisi, S.Ag., M.Pd (Kepala Balai Diklat Keagamaan Medan) menyatakan bahwa Balai Diklat
Keagamaan Medan tentu saja selalu berkoordinasi dengan pihak KPKNL terkait penetapan status, inventarisasi dan penghapusan BMN sedangkan mengenai sosialisasi terhadap pegawai dan widyaiswara di lingkungan Balai Diklat Keagamaan Medan sejauh ini sedikit yang memahami perihal penatausahaan BMN yang disebabkan kurangnya sosialisasi pengelola terhadap pengguna barang (Wawancara tanggal 4 Mei 2021, Pukul 11.00 WIB)

Hasil wawacara dengan Suhesti Wira Dharma., M.A. (Ka.Subbag Tata Usaha) menjelaskan, bahwa Balai Diklat Keagamaan Medan sudah berkoordinasi dengan pihak KPKNL Medan dalam melakukan penetapan status BMN, penghapusan BMN serta penginventarisasian barang namun terkait dengan dan sosialisasi BMN terhadap pegawai memang bisa dibilang masih sangat sedikit, yang berdampak kepada banyaknya pegawai yang kurang memahami penatausahaan BMN dan bahkan tidak mau memamahinya sehingga tidak jarang ada barang yang tidak pada tempatnya lagi karena setelah digunakan oleh sipengguna tidak dikembalikan ketempat semula (Wawancara tgl 7 April 2021 Pukul 15.30 WIB)

Ayulina, S.E (Pengelola BMN) juga menyatakan hal yang sama sebagaimana Balai Diklat Keagamaan Medan selalu berkoordinasi dengan pihak KPKNL Medan dalam hal untuk melakukan penetapan status BMN, penghapusan BMN serta penginventarisasian barang terkait dengan penghapusan barang terakhir dilakukan pada tahun 2019 dan pada tahun ini kemungkinan akan dilakukan kembali terhadap beberapa barang 
serta ketika dilakukan penghapusan, Ayulina, S.E selaku Pengelola BMN melakukan penataan ulang BMN di aplikasi BMN (Wawancara tgl 7 April 2021 Pukul 15.30 WIB)

Hasil wawancara dengan Ichwan Fachriza (Wawancara tanggal 28 April 2021, pukul $13.00 \mathrm{Wib}$ ). menyatakan bahwa selama ini Balai Diklat Keagamaan Medan sudah berkoordinasi dengan pihak KPKNL terkait hal penetapan status BMN, Inventarisasi serta penghapusan BMN terkait dengan sosialisasi penatausahan barang milik negara dapat dikatakan belum maksimal dilakukan dan tentu saja hal ini berdampak langsung kepada banyaknya pegawai yang kurang memahami bagaimana cara melaksanakan penatausahaan barang milik negara yang sesuai dengan prosedur.

Drs. Luthfi Maulana Nasution, M.Pd. selaku pengguna barang tidak begitu mengetahun apakah Balai Diklat Keagamaan Medan apakah sudah berkoordinasi ataupun belum dengan pihak KPKNL mengingat pekerjaan beliau tidak bersentuhan langsung dengan Barang Milik Negara namun terkait sosialisasi beliau menyatakan bahwa perlu agar ada sosialisasi sehingga pengguna barang dapat mengikuti prosedur yang ada terkait barang milik negara mengingat barang milik negara adalah barang yg diperoleh atas beban Anggaran Pendapatan dan Belanja Negara atau berasal dari perolehan lainnya yang sah yang tentunnya harus dipertanggung jawabkan penggunaannya (Wawancara tanggal 4 Mei 2021, Pukul 9.00 WIB)

Pengukuran efektivitas menurut Duncan adalah adanya integrasi, jika dilihat dari hasil wawancara dengan Ka.
Balai, Ka.Subbag Tata Usaha, pengelola serta pengguna barang milik negara menjelaskan bahwasanya pelaksanaan integrasi yaitu melakukan koordinasi dengan instansi luar terkait serta sudah melaksanakan sosialisasi kepada pegawai lain, jika dikaitkan dengan teori Duncan integrasi yang merupakan pengukuran efektivitas dinilai efektif.

Dari seluruh wawancara

berdasarkan informan yang memberikan informasi serta hasil penelitian langsung ke Balai Diklat Keagamaan Medan mengenai perihal pengukuran efektivitas menurut teori Campbell J.P keberhasilan program dan keberhasilan sasaran, serta pengukuran efektivitas menurut Duncan yaitu integrasi diambil kesimpulan bahwa pengukuran efektivitas yang kurang efektif pada kebijakan penatausahaan barang milik negara di Balai Diklat Keagamaan Medan antara lain (1) Pelaksanaan Inventarisasi yang merupakan indikator dari pengukuran efektifitas keberhasilan program dan keberhasilan sasaran yaitu suatu mekanisme untuk mempertahankan kebijakan yang ada hal ini dikarenakan minimnya SDM pengelola barang milik negara, dan (2) Sosialisasi terhadap pegawai Balai Diklat Keagamaan Medan perihal pelaksanaan penatausahaan barang milik negara dalam hal ini belum banyak diketahui oleh khalayak banyak, sosialisasi merupakan pengukuran efektifitas Duncan yaitu bagian dari intergrasi.

Penatausahaan Barang Milik Negara bertujuan untuk mewujudkan tertib administrasi dan mendukung tertib pengelolaan Barang Milik Negara yang meliputi penatausahaan pada Pengguna/Kuasa Pengguna Barang dan 
Pengelola Barang sebagaimana diatur dalam Peraturan Menteri Keuangan Nomor: 120/PMK.06/2007 perihal Penatausahaan Barang Milik Negara (BMN). Penatausahaan Barang Milik Negara adalah rangkaian kegiatan yang meliputi Pembukuan, Inventarisasi, dan Pelaporan Barang Milik Negara sesuai dengan ketentuan yang berlaku.

Pelaksanaan pembukuan BMN di Balai Diklat Keagamaan Medan sudah bagus dan memenuhi prosedur yang sudah ditentukan hal ini dapat dilihat pengelola BMN diinstansi Balai Diklat Keagamaan sudah menggunakan Sistem Manajemen Akuntansi Barang Milik Negara (SIMAK-BMN) yang sudah berstandar nasional yang memang aplikasi ini sudah digunakan oleh seluruh kementerian sehingga semua barang yang sudah lama dan baru diadakan juga tercatat dalam aplikasi tersebut, sehingga memudahkan penggunannya untuk melakukan pemprosesan data BMN yang ada baik itu pengelompokan jenis atau akun barang dan pengelompokan waktu perolehan barang tersebut dan Balai Diklat Keagamaan Medan mendapatkan ranking 1 dalam hal rekonsiliasi laporan Sistem Akutansi Instansi (SAI) di lingkungan Litbang Kementrian Agama.

Hanya saja terkait Inventarisasi yang diakukan di Balai Diklat Keagamaan Medan berdasarkan keterangan wawancara yang didapat dari Key Informan menunjukan masih kurang maksimal dilakukan oleh pengelola BMN, dapat dilihat di lapangan dan dari data yang ada misalnya Kartu Inventarisasi Barang (KIB) / Daftar Inventarisasi Barang (DIR) yang tergantung di setiap ruangan data yang ada di KIB/DIR tersebut sudah lama tidak diperbaharui hal ini tentunya menjadi kendala dalam keberhasilan sasaran yang merupakan indiktor dari efektivitas untuk mempertahankan sasaran yang sudah ditentukan dari program yang sudah ditetapkan.

Dalam hal pelaksanakan penatausahaan BMN tidak terlepas dari inventarisasi, inventarisasi wajib dilakukan agar barang bergerak maupun tidak bergerak untuk tetap diketahui jumlah yang sudah dicatat agar sesuai dengan kondisi fakta barang yang ada dilapangan/tempat, dengan inventarisasi dapat diketahui berapa kuantitas barang yang ada.

Pelaporan adalah proses penyusunan laporan barang setiap semester dan setiap tahunnya setelah dilakukan inventarisasi dan pencatatan, laporan merupakan bagian yang tidak terlepas dari penatausahaan BMN, hal ini berdasarkan wawancara dari Key informan dan melihat langsung dokumen di Balai Diklat Keagamaan Medan bahwanya pelaporan BMN sudah dilaksanakan dengan menggunakan aplikasi SIMAK-BMN serta sudah berkoordinasi dengan pihak Kantor Pelayanan Kekayaan Negara dan Lelang (KPKNL) sehingga data BMN yang ada sudah akuntabilitas sebagai bentuk penatausahaan BMN, dimana akuntabilitas merupakan pertanggungjawaban yang terkait dengan dipatuhinya prosedur yang digunakan untuk melaksanakan penatausahaan BMN di Balai Diklat Keagamaan Medan, dimana pelaporan BMN dilakukan persemester yang dilaporan ke KPKNL Medan yaitu pada bulan Januari dan Juli serta Dokumentasi pelaporan BMN tersebut tersimpan secara aplikasi maupun cetakan yang 
sudah terjilid sehingga memudahkan tim pengawas dan pejabat terkait untuk melihat nilai aset dan jumlah barang yang ada sehingga penaatausahaan BMN dapat berjalan. Berdasarkan ketentuan Pasal 6 Peraturan Pemerintah Nomor 27 Tahun 2014 tentang Pengelolaan Barang Milik Negara/Daerah ditetapkan bahwa Menteri Agama selaku Pengguna Barang diharuskan menyusun Laporan Barang Milik Negara berupa Laporan Barang Milik Negara Semesteran dan Laporan Barang Milik Negara Tahunan.

Periode Pelaporan pada Laporan Barang Milik Negara ini dijelaskan pada 1) Neraca. Neraca adalah laporan yang menggambarkan posisi keuangan mengenai aset, kewajiban, dan ekuitas pada tanggal periode pelaporan. Dalam hal ini, neraca yang disajikan merupakan Neraca Barang Milik Negara yang terdiri dari Aset Lancar, Aset Tetap, Aset Lainnya, Akumulasi Penyusutan Aset Tetap, serta Akumulasi Penyusutan Aset Lainnya. 2) Laporan Barang Milik Negara, Laporan Barang Milik Negara adalah laporan yang menggambarkan posisi Barang Milik Negara pada tanggal periode pelaporan. Laporan Barang Milik Negara ini disajikan berdasarkan kelompok barang yang terdiri dari Intrakomptabel, Ekstrakomptabel dan Gabungan. 3) Catatan atas Laporan Barang Milik Negara, Catatan atas Laporan Barang Milik Negara atau lebih dikenal dengan Catatan Ringkas Barang menguraikan secara rinci atas nilai Barang Milik Negara perkiraan neraca termasuk kebijakan akuntansi yang digunakan untuk masing-masing perkiraan. Laporan Barang Milik Negara Tahunan periode pelaporan Tahun 2020 telah disusun dan disajikan sesuai dengan Peraturan Pemerintah Nomor 71 Tahun 2010 tentang Standar Akuntansi Pemerintah Pusat dan Peraturan Pemerintah Nomor 27 Tahun 2014 tentang Pengelolaan Barang Milik Negara/Daerah.

Pelaksanaan penatausahaan barang milik negara di Balai Diklat Keagamaan Medan sudah berpedoman pada Permenkeu Nomor 120/PMK.06/2007 dengan sudah dilaksanakannya pembukan, inventarisasi, dan pelaporan. Jika dikaitkan dengan teori Campbell J.P dalam pengukuran efektivitas harus adanya keberhasilan program dan keberhasilan sasaran dalam efektivitas kebijaksanaan penatausahan barang milik negara agar kebijakan penatausahaan efektif maka harus mencakup adanya pelaksanaan antara lain : Pembukuan, Inventarisasi dan Pelaporan, pada instansi Balai Diklat Keagamaan Medan pembukuan dan pelaporan sudah berjalan dengan efektif terlihat dengan sudah menggunakan aplikasi pembukuan barang milik negara sehingga memudahkan pencarian dan pembuatan data BMN di Balai Diklat Keagamaan Medan, dan seiring dengan adanya pembukuan yang sudah menggunakan aplikasi maka hasil laporan dapat dirinci secara detail dan memberikan informasi yang lengkap, tetapi pada pelaksanaan invetarisasi di Balai Diklat Keagamaan Medan belum efektif dikarenakan faktor sumber daya manusianya, inventarisasi juga merupakan satuan yang tidak terlepas dari pengukuran efektivitas sasaran yaitu suatu mekanisme untuk mempertahankan kebijakan, sehingga dengan kurangnya faktor sumber daya manusia maka instansi Balai Diklat 
Keagamaan Medan perlu menambah pegawai yang berkompeten lainnya untuk mengikuti pelatihan mengenai barang milik negara.

Dari hasil pembahasan dapat diambil kesimpulan bahwasanya keberhasilan program dan keberhasilan sasaran sebagai ukuran efektivitas kebijakan menurut Teori Campbell JP masih kurang efektif hal ini dikarenakan masih adanya salah satu indikator yaitu inventarisasi belum maksimal dilaksanakan.

dalam $\begin{array}{cr}\text { Faktor Sumber Daya Manusia } \\ \text { efektivitas }\end{array}$
penatausahaan BMN di Balai Diklat Keagamaan Medan masih belum memadai, hal ini bisa dilihat langsung saat penelitian di lapangan pengelola BMN merangkap tugas mulai dari melakukan penginputan data barang ke aplikasi, membuat catatan manual, melakukan penetapan status, melakukan penghapusan, memberikan pengkodean pada barang, membuat Kartu Inventaris Barang (KIB), membuat laporan BMN, hingga petugas BMN tersebut juga merangkap melaksanakan tugas untuk pekerjaan Administrasi Umum lainnya. Dalam efektivitas penatausahaan BMN juga tidak terlepas dari harus adanya pengelola gudang yang secara permanen mengurusi barang yang disimpan dan dikeluarkan sehingga hal ini menghambat penatausahaan BMN.

Kurang pedulinya serta ketidakinginan untuk melaksanakan prosedur penatausahaan BMN bagi pegawai juga dapat terlihat, dimana efektivitas kebijakan penatausahaan BMN juga tidak terlepas dari pegawai sebagai pengguna BMN, keperdulian serta ikut turut menjaga ketertiban BMN harus didukung oleh pegawai dimana terkadang adanya pegawai yang kurang perduli akan barang yang digunakan, sehingga barang yang sudah ditempatkan di suatu ruangan bisa berpindah-pindah ketempat lainnya sehingga hal ini tidak menutup kemungkinan barang yang ada diruangan sudah tidak sesuai dengan catatan yang ada didaftar KIB, hal ini terkadang sangat menyulitkan pengelola BMN dimana barang yang dipindahkan tidak memberitahukan terlebih dahulu kepada pengelola BMN. Hal ini juga dikarenakan kurangnya sosialisasi terhadap pegawai sehingga banyak pegawai yang kurang memahami prosedur penatausahaan BMN.

Untuk mencapai tujuan efektivitas kebijakan penatausahaan BMN pengendalian aset merupakan salah satu unsur dari penatausahaan BMN terutama untuk barang bergerak dalam hal ini barang yang dapat dipindahpindahkan. Beberapa kebijakan prosedurnya antara lain:

1) Ruang Penyimpanan Aset (Gudang), ruang penyimpanan aset sangatlah dibutuhkan dimana barang yang diadakan tetapi belum disalurkan kepada unit/bagian yang membutuhkan harus disimpan terlebih dahulu di ruang penyimpanan (gudang barang) agar keamanan barang tesebut tidak hilang.

2) Pembatasan Ruang Penyimpanan (Gudang), dikarenakan ruang penyimpanan merupakan tempat barang-barang yang baru dan lama yang merupakan aset yang memiliki nilai yang tinggi maka untuk masuk dalam ruang penyimpanan juga harus dibatasi, yang dapat masuk dalam ruang penyimpanan hanyalah petugas dan pengelola BMN. Di Balai Diklat Keagamaan Medan sudah 
disediakannya satu ruangan khusus yaitu gudang untuk penyimpan barang barang yang baru dibeli tetapi belum didistribusikan kebagian yang membutuhkan.

3) Stock Opname dan Inventarisasi, Stock opname inventarisasi harus dilakukan, stock opname barang untuk dilakukan dalam 6 bulan sekali sedangkan untuk inventarisasi dilakukan dengan menginput sisa barang yang belum didistribusikan ke aplikasi persediaan barang.

4) Pemberiaan Label pada Aset, pemberian label pada aset harus dilakukan hal ini untuk mengetahui berapa jumlah aset tersebut dan tahun berapa perolahan asetnya sehingga hal ini membantu dalam penginventarisasian BMN yang dilakukan setiap tahunnya. Dalam hal ini Balai Diklat Keagamaan Medan masih belum melaksanakan pelabelan nomor yang mencakup kode instansi, kode barang, tahun pembelian serta jumlah kode barang terhadap barang yang akan didistribusikan.

Pengendalian aset merupakan bagian yang penting dalam hal pelaksanaan penatausahaan barang milik negara contohnya dengan melakukan penyimpanan, pemberian kode barang adalah beberapa langkah untuk pengendalian aset, saat ini Balai Diklat Keagamaan Medan sudah memiliki gudang penyimpanan barang yang belum didistribusikan ke bagian yang membutuhkan namun Balai Diklat Keagamaan Medan belum memberikan pelabelan akan barang yang akan didistribusikan kesetiap ruangan. Pelaksanaan pengendalian aset merupakan rangkaian dari penatausahaan barang milik negara, hal ini jika dikaitkan degan pedoman Permenkeu Nomor. 120/PMK.06/2007 Balai Diklat Keagamaan Medan belum maksimal melaksanakan pengendalian aset, dan menurut pengukuran efektivitas hal ini merupakan salah satu pengukuran efektivitas keberhasilan sasaran yaitu inventarisasi yang suatu mekanisme melakukan pengendalian aset. terkait dalam hal ini pengendalian aset untuk pelaksanaan penatausahaan barang milik negara dinilai masih kurang efektif.

Dari pembahasan mengenai penatausahaan milik negara di Balai Diklat Keagamaan Medan berdasarkan Pedoman pada Permenkeu Nomor 120/PMK.06/2007 dan jika dikaitkan dengan teori Campbell J.P dan Duncan bahwa pengukuran efektifitas kebijakan penatausahan barang milik negara di Balai Diklat Keagamaan Medan dapat dilihat bahwa pembukuan, pelaporan serta Integrasi berkordinasi dengan instansi lain sudah efektif.

Hanya saja untuk inventarisasi di Balai Diklat Keagamaan Medan kurang efektif, hal ini dikarenakan masih minimnya tenaga pengelola barang milik negara, inventarisasi dalam pengukuran efektifitas Campbell J.P merupakan suatu keberhasilan sasaran yaitu suatu mekanisme atau pun cara untuk mempertahankan suatu kebijakan yang ada agar tetap dapat berjalan dengan baik sehingga dapat mencapai tujuan yang diharapkan tapi dalam hal ini inventarisasi masih kurang maksimal hal ini dikuatkan oleh bukti dukung Kartu Inventaris Barang yang tidak diperbaharui datanya lebih dari 6 tahun. Hal tersebut dukung pula oleh kurangnya pemahaman perihal penatausahaan barang milik negara oleh 
sipengguna dalam hal ini sipengguna adalah pegawai yang disebabkan oleh kurangnya sosialisasi terkait Barang Milik Negara, serta kurang perdulinya pengguna tersebut dalam menjaga keamanan barang. Jika dikaitkan dengan teori Campbell J.P dan teori Duncan maka pengukuran efektivitas dikatakan kurang efektif,

Solusi akan kurang efektifnya inventarisasi dan sosialisasi terhadap pegawai, kedepannya Balai Diklat Keagamaan Medan akan memperbaikinya dengan mengikutkan pelatihan pegawai yang akan ditempatkan sebagai pengelola BMN serta akan mengadakan sosialisasi penatausahaan barang milik negara terhadap seluruh pegawai Balai Diklat Keagamaan Medan sebagai pengguna barang.

\section{SIMPULAN}

Kebijakan penatausahaan Barang Milik Negara (BMN) yang dilaksanakan di Balai Diklat Keagamaan Medan saat ini kurang efektif hal ini dapat dilihat dari hasil wawancara serta hasil penelitian kelokasi langsung bahwa pelaksanaan penatausahaan BMN di Balai Diklat Keagamaan Medan Medan didapatkan kesimpulan antara lain: 1) Pelaksanaan pembukuan pada instansi Balai Diklat Keagamaan Medan sudah efektif ini terlihat dan di buktikan dengan adanya pencatatan barang milik negara yang sudah menggunakan aplikasi sehingga data-data barang milik negara dapat memberikan informasi yang lengkap, menjelaskan jumlah, harga, tahun perolehan serta merk barang. 2) Pelaksanaan inventarisasi pada instansi Balai Diklat Keagamaan Medan belum efektif hal ini terlihat dari hasil wawacara serta peneliti melihat langsung menunjukan data Kartu Inventaris Barang yang ada setiap ruangan dan laporan penilian kembali barang milik negara sudah melebih waktu yang tentukan tetapi belum juga dilakukan kembali pengecekan fisik barang ke lapangan. 3) Pelaksanaan pelaporan di Balai Diklat Keagamaan Medan sudah berjalan efektif hal ini dibuktikan langsung ke lokasi oleh peneliti dengan melihat langsung berkas-berkas laporan barang milik negara sudah lengkap yang dibuat persemester dalam hal ini dalam 1 tahun 2 kali membuat laporan dan laporan BMN tersebut juga dibuat dari aplikasi yang dihubungkan langsung dengan aplikasi pembukuan BMN sehingga hasil laporan tersebut akurat dan dapat memberikan informasi yang jelas keadaan barang milik negara dalam 1 tahun serta tidak luput juga Balai Diklat Keagamaan Medan juara 1 dalam hal rekonsiliasi laporan SAI di lingkungan Badan Litbang Kementrian Agama. 4) Integrasi pada Balai Diklat Keagamaan Medan untuk koordinasi dengan instansi lain sudah dilaksanakan dan efektif dalam hal ini Balai Diklat Keagamaan Medan melakukakan koordinasi dengan Kantor Pelayanan Kekayaan Negara (KPNL), tetapi pada sosialisasi terhadap pegawai sebagai pengguna barang masih belum efektif dikarenakan belum maksimalnya sosialisasi terhadap pegawai, sehingga banyak pegawai di Balai Diklat Keagamaan Medan yang belum memahami penatausahaan barang milik negara.

Faktor-Faktor yang menjadi kendala pelaksanaan kebijakan penatausahaan BMN di Balai Diklat Keagamaan Medan berdasarkan hasil wawancara dengan informan dan fakta 
yang dilihat langsung dilapangan oleh peneliti antara lain: 1) Kurangnya SDM Pengelola BMN ini dapat terlihat pengelola BMN yang ada 1 orang yang melakukan pencatatan, penginventarisasian, pelaporan, penghapusan dan terkadang tidak ubahnya seperti helper/office boy yang mengantar barang milik negara tersebut ke pengguna secara langsung serta tidak adanya petugas gudang permanen dan petugas pengelola BMN tersebut juga harus melaksanakan pekerjaan umum lainnya, sehingga pelaksanaan inventarisasi yang merupakan bagian dari keberhasilan sararan untuk mempertahankan kebijakan yang sudah ditentukan belum dapat berjalan maksimal ini dapat terlihat pelaksanaan inventarisasi yang seharusnya dilakukan setiap setahun sekali tetapi dari fakta yang didapatkan lebih dari 6 (enam) tahun. 2) Kurangnya pemahaman prosedur penatausahaan BMN pada pegawai meskipun sudah ada SOP tentang Barang Milik Negara. 3) Kurang pedulinya pemakai BMN dalam hal ini pegawai dimana pegawai yang menggunakan BMN kurang merawat dan menjaga barang tersebut sehingga terkadang barang yang sudah dipinjamkan/disahkan kepada pegawai atau pun penanggungjawab ruangan tersebut bisa berpindah-pindah keruangan lain.

\section{SARAN}

Berdasarkan hasil penelitian dan kesimpulan yang telah dijelaskan sebelumnya, peneliti memberikan saran bahwa bagi pengelola Barang Milik Negara untuk mempedomani Peraturan Menteri Keuangan Nomor 181/PMK.06/2016 dan membuat daftra atau dokumen untuk izin pemakaian dan pemindahan barang serta penomoran label terpasang secara keseluruhan. Kartu Inventaris barang persediaan agar tetap konsisten dicetak setiap tri wulan, dan adanya himbauan dan sosialisasi terhadap pegawai yang menggunakan barang milik negara untuk merawat dan menjaga barang milik negara tersebut.

\section{DAFTAR PUSTAKA}

Campbell, J.P. (1989) Teori Efektivitas, dalam Richard M: Efektivitas Organisasi (2005) Bandung: Erlangga

Cholid. (2008). Metodologi Penelitian, Jakarta: PT Bumi Aksara.

Duncan dalam Steers, R. M. (1985). Efektivitas Organisasi. dalam Zulkarnain. 2012., Jakarta

Keputusan Menteri Keuangan Nomor 403/KM.6/2013 tentang Pedoman Pelaksanaan Tindak Lanjut Hasil Penertiban Barang Milik Negara pada Kementerian/Lembaga;

Noor, Juliansyah. (2012). Metodologi Penelitian. Jakarta: Kencana Prenada Media Group.

Nurwahid, (2013), Penelitian Implementasi Penatausahaan Barang Milik Negara di KPPN Palembang, Palembang

Mutiarin, D. (2014). Manajemen Birokrasi dan Kebijakan. Yogyakarta: Pustaka Pelajar.

Peraturan Menteri Dalam Negeri No. 17 Tahun 2007. Tentang Pedoman Pengelolaan Aset /Barang Milik Daerah.

Peraturan Menteri Keuangan Nomor 177/PMK.05/2015 tentang Pedoman Penyusunan dan Penyampaian Laporan Keuangan Kementerian Negara/Lembaga;

Peraturan Menteri Keuangan Nomor 181/PMK.06/2016 tentang

Penatausahaan Barang Milik Negara;

Peraturan Menteri Keuangan Nomor 244/PMK.06/2012 tentang Tata Cara Pelaksanaan Pengawasan dan Pengendalian Barang Milik Negara 
sebagaimana telah diubah dengan

Peraturan Menteri Keuangan Nomor 52/PMK.06/2016;

Peraturan Menteri Keuangan Nomor 29/PMK.06/2010 tentang

Penggolongan dan Kodefikasi Barang Milik Negara;

Peraturan Pemerintah Nomor 71 Tahun 2010 tentang Standar Akuntansi Pemerintahan.

Peraturan Pemerintah Republik Indonesia Nomor 27 tahun 2014

Peraturan Pemerintah Republik Indonesia Nomor 6 Tahun 2006 Tentang Pengelolaan Barang Milik Negara/Daerah

Peraturan Presiden Republik Indonesia Nomor 54 Tahun 2010 Tentang Pengadaan Barang/Jasa Pemerintah.
Permenkeu, Nomor 120/PMK.06/2007 tentang Penatausahaan Barang Milik Negara

Permentan, Nomor 78/PMK.06/2014 tentang Pengelolaan Baang Milik Negara

Sugiyono. (2016). Metode Penelitian Kuantitatif, Kualitatif dan R\&D. Bandung: PT Alfabet.

Sugiyono. (2013). Metode Penelitian Pendidikan Pendekatan Kuantitatif, Kualitatif, dan R\&D. Bandung: Alfabeta.

Syamsuddin dan Vismaia S. Damaianti. Metode Penelitian Pendidikan Bahasa, (Bandung: Remaja Rosdakarya, 2006), 73.

Tohirin. (2013). Metode Penelitian Kualitatif Dalam Pendidikan Dan Bimbingan Konseling. Jakarta: PT Raja Grafindo Persada. 